\title{
INDIVIDUAL FINANCIAL DECISIONS \\ IN RETIREMENT SAVING PLANS AND \\ THE PROVISION OF RESOURCES \\ FOR RETIREMENT
}

James M. Poterba

David A. Wise

Working Paper 5762

\section{NATIONAL BUREAU OF ECONOMIC RESEARCH 1050 Massachusetts Avenue \\ Cambridge, MA 02138 \\ September 1996}

We are grateful to Jeff Brown, Jeff Close, Peter Diamond, Matthew Eichner, Martin Feldstein, Brett Hammond, Thomas Hungerford, Thomas Juster, John Rea, Andrew Samwick, and Jack VanDerhei for helpful comments or assistance with data analysis, and to the National Institute on Aging, the National Bureau of Economic Research, the National Science Foundation (Poterba), James Phillips Fund (Poterba), and the Hoover Institution (Wise) for research support. This paper is part of NBER's research programs in Aging and Public Economics. Any opinions expressed are those of the authors and not those of the National Bureau of Economic Research.

(C) 1996 by James M. Poterba and David A. Wise. All rights reserved. Short sections of text, not to exceed two paragraphs, may be quoted without explicit permission provided that full credit, including $(\mathcal{C}$ notice, is given to the source. 


\title{
INDIVIDUAL FINANCIAL DECISIONS \\ IN RETIREMENT SAVING PLANS AND \\ THE PROVISION OF RESOURCES \\ FOR RETIREMENT
}

\begin{abstract}
Proposals for mandatory private saving accounts differ in the degree of investment discretion that they provide to individual savers, and in their provisions for annuitization of accumulated assets. With respect to investment choices, some argue that individuals must be prevented from investing too conservatively, and earning low returns over their accumulation period, while others argue that individuals should be protected from recklessly investing their retirement assets. With respect to annuitization, there is concern that individuals might not choose annuities and would thereby expose themselves to a risk of outliving their assets in a privatized system. This paper draws on the existing experience with 401(k) plans and other defined contribution pension plans to provide evidence on each of these issues. We find that the share of $401(\mathrm{k})$ plan assets held in corporate equities has increased substantially in recent years. We are only able to provide limited evidence on participant asset management, since many $401(\mathrm{k})$ plans have limited options in this regard. We do find, however, that a participant's education and income levels are related to asset allocation decisions, with less educated and lower income participants less inclined to invest in equity securities. We also analyze a unique data base on TIAA-CREF participants and find several attributes of annuitization behavior that seem inconsistent with standard behavior in the lifecycle model.
\end{abstract}

James M. Poterba

Department of Economics

MIT, Room E52-350

Cambridge, MA 02139-4307

and NBER

poterba@mit.edu
David A. Wise

Kennedy School of Government

Harvard University

79 John F. Kennedy Street

Cambridge, MA 02138

and NBER

dwise@nber.harvard.edu 
Two important design features in proposals to supplement or replace the current Social Security system with a system of individual saving accounts are the degree of individual autonomy that would be allowed with respect to the investment of accumulating assets, and with respect to the distribution of accumulated assets. At one extreme are proposals that would mandate the allocation of assets between stocks, bonds, and other investment categories during the accumulation phase, and require the purchase of a government-provided annuity at retirement. At the other extreme are plans that would allow substantial individual choice in the investment of assets, and in the time profile and method of distributing accumulated assets.'

Asset allocation decisions can have important implications for the rete of return on retirement assets, and hence on the degree of retirement security that a given stream of individual contributions during the working life can provide. The standard source of data on long-term returns, Ibbotson Associates (1995), reports that since 1926, the distribution of returns on a diversified portfolio of corporate stocks has a mean of 9.9 percent per year, compared with a mean of 4.8 percent for a portfolio of long-term bonds and 3.8 percent, barely more than the inflation rate, for a portfolio of short-term Treasury bills. Siegel (1994) presents similar findings using data from 1802-1992: the mean equity return is 8.1 percent, the mean bond return 4.7 percent, and the mean inflation rate 1.3 percent. The expected value at retirement of an accumulated retirement fund invested in equities is greater than the expected value of one invested in less risky fixed income assets, although there is also a greater chance of having sustained losses on such a portfolio.

Mandatory saving plans that provide substantial investment discretion to individual participants have led to discussion of two conflicting concerns regarding individual asset

\footnotetext{
'Diamond and Valdes-Prieto (1994) and Foldstein (1996) discuss a range of issues that arise in considering Social Security reform proposals.
} 
management choices. One is the possibility that some individuals will invest conservatively, thereby earning low rates of return on their account balances and thus not accumulating sufficient resources to finance retirement consumption. The other concern is that some individuals will invest their accounts recklessly, bearing substantial risk and incurring substantial probability of reaching retirement with a very small account accumulation. It is in principle possible that each of these investment patterns might apply to some part of the population, so that the group reaching retirement with low levels of resources would consist of some conservative investors and some plungers. ${ }^{2}$ Restricting asset allocation options provides one way to avoid either of these outcomes.

It is difficult to evaluate the importance of restricting individual investment choice, since there has never been a universal system of retirement saving accounts in the United States. A substantial fraction of U.S. households accumulates very little financial wealth (see Poterba, Venti, and Wise (1994a)), instead relying primarily on Social Security and to a lesser extent corporate pensions to sustain retirement consumption. Another group, which does accumulate some financial wealth, tends to hold only fixed-income instruments in their portfolio. It is difficult to gauge how such housoholds would invest their retirement saving assets, if they were provided with the chance to do so. A particularly difficult issue is how a potential reduction in the current level of Social Security benefits, which provide a real annuity "floor" under retirement consumption, would affect asset allocation choices earlier in the lifetime.

A related set of issues arises with respect to payouts from mandatory saving accounts. One of the risks that is partially insured by current defined benefit pension plans (through

\footnotetext{
${ }^{2}$ The average return to all investors in a cohort might not be affected by the presence of some very conservative, and some risk-loving, investors, but the distribution of wealth at retirement would be affected.
} 
annuity contracts purchased with the accumulation in defined contribution pension plans) and by Sacial Security is the risk of outliving one's resources. Mandatory saving plans that require annuitization of accumulated balances at retirement or at a particular age, such as 65, also provide a guarantee that resources will be spread over an individual's remaining lifetime. Such plans also entail tighter restrictions on individual choice than plans that would allow more discretion in asset withdrawal, and they may involve additional government involvement in the provision of annuities or the oversight of the private annuity market.

At the center of the discussions of both accumulation and withdrawal options are questions of how individuals and couples would behave in a system of mandatory saving accounts. One potential source of information on these issues is the behavior of participants in various targeted retirement saving plans, such as Individual Retirement Accounts (IRAs), Salary Reduction Arrangements (SRAs), 401(k) plans, and other self-directed defined contribution pension plans. The growth of such targeted retirement saving plans has expanded the set of individuals with substantial financial asset holdings and some discretion regarding their investment. The participants in these plans tend to have higher incomes than non-participants, so there are immediate questions about the degree to which findings based on such groups can be generalized to the population as a whole. Nevertheless it seems appropriate to examine the behavior of participants in these plans and to extract what information is available about accumulation and distribution behavior.

This paper considers a range of different saving vehicles that provide individuals with some discretion in investment and some opportunity to choose the nature of their payouts, including IRAs, SRAs, 401(k) plans, the TIAA/CREF retirement system for college and university emplovees, and the federal government's thrift saving plan. It provides evidence on individual financial decisions in these plans. 
The paper is divided into five sections. The first presents summary information on participation in various retirement saving programs, drawing on data from the 1992 Survey of Consumer Finances and the recently-released Health and Retirement Survey. Section two summarizes asset allocation decisions in a variety of the existing saving plans. We note that available evidence from $401(k)$ plan providers suggests that the equity allocation of new contributions to $401(\mathrm{k})$ plans is greater than that for the existing stock of assets, and that there are differences by age and income in the asset allocation pattern in $401(\mathrm{k})$ plans. Section three focuses on both accumulation and withdrawal decisions of TIAA-CREF participants, and summarizes the allocation of retirement saving contributions between stocks and fixed-income assets. The fourth section considers the demand for annuities among TIAACREF participants, and relies in particular on a 1988 surver of both TIAA-CREF retirees to explore how individual characteristics affect annuity demand. There is a brief conclusion that suggests several issues for further investigation.

\section{The Growth of Participation in Targeted Retirement Savino Plans}

In the last decade and a half, the structure of the private pension system has shifted substantially from defined-benefit (DB) to defined-contribution (DC) plans, and many individuals have taken advantage of opportunities for tax-deferred saving in targeted retirement saving accounts. The result of these changes has been a shift, small for those already retired but potentially much greater for those who will retire in the future, toward retirement saving accounts that rely in some way on individual investment decisions.

The first substantial targeted retirement saving plan was the Individual Retirement Account (IRA). IRAs were introduced for most households in 1981, and rose to substantial popularity, with nearly 16 million contributors, before the 1986 Tax Reform Act curtailed the 
tax benefits for IRA participation by higher-income households. Since 1986 the flow of new contributions to IRAs has been substantially reduced, but total assets in IRAs have continued to grow as a result of roll-over contributions from other retirement plans, and the increase in value of previously invested assets. By the end of 1995, Bernstein Research (1995) estimates that nearly $\$ 1$ trillion was held in IRAs.

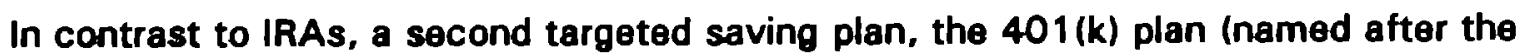
section of the Internal Revenue Code that created it), has expanded rapidly since the early 1980s. Although formally created in $1978,401(\mathrm{k}) \mathrm{s}$ did not gain popularity until after 1981 , when the Treasury Department issued clarifying regulations that made it possible for employers to establish such plans. These plans have diffused rapidly through the workplace, first at large employers and then at smaller firms. $401(k)$ participants can defer income tax liability on their contributions. Assets in $401(k)$ accounts accumulate tax-free and income from these plans is taxed when the funds are withdrawn. Prior to 1987, emplovees could contribute up to $\$ 30,000$ each year to a $401(\mathrm{k})$ plan. The Tax Reform Act of 1986 reduced the limit to $\$ 7,000$ beginning in 1987 and instituted indexation for inflation in subsequent years. The contribution limit was $\$ 9,235$ for the 1995 tax year. Many employers match employee contributions to $401(k)$ plans, often at rates between 50 and 100 percent (see Poterba, Venti, and Wise (1994b)l. The number of participants in 401 (k) plans has increased from 7.5 million in 1984 , to 15.2 million in 1988 , to 22.4 million in 1992 , the most recent year for which the Department of Labor (1996) has released detailed information from IRS Form 5500 filings. Bernstein Research (1995) estimates that the market value of assets in $401(k)$ plans was approximately $\$ 650$ billion at the end of 1995, and that these assets will increase rapidly in the future. Contributions to IRAs and $401(\mathrm{k})$ plans now exceed contributions to traditional employer-provided defined benefit pension plans. 
Both IRAs and $401(\mathrm{k}) \mathrm{s}$ provide individuals with opportunities to make financial decisions about the investment of retirement plan assets, and about the distribution of these assets after retirement age. Individuals have substantial the greatest discretion in investing IRA assets. Although some assets, such as gold and silver coins and hedge funds, could not be held in IRAs until recently, these restrictions are unlikely to constrain the investment choices of many IRA participants. IRA assets can be withdrawn in various ways, including lump-sum payouts at any age (although such payouts before age $591 / 2$ incur a 10 percent penalty tax upon withdrawal), according to a schedule of participant age-specific minimum distributions determined by the IRS, or by purchasing an annuity.

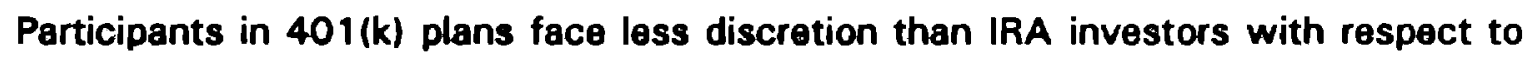
asset allocation. The available investment options are plan-specific and as such are determined by the employer's arrangement with the $401(k)$ provider. Since 1993, however, Department of Labor guidelines have required that all $401(k)$ plans offer at least three investment options, including a broad-based equity fund, a bond fund, and a money market fund. Many $401(\mathrm{k})$ plans offer a more diverse range of investment options. Assets can be withdrawn from 401 (k) plans at any time, although lump-sum withdrawals before age $591 / 2$ that are nat rolled-over into other tax-deferred retirement saving plans incur the same 10 percent penalty tax as withdrawals from IRAs. Some 401 (k) plans offer annuitization options, while others can be annuitized only if the individual participant purchases an annuity in the private insurance market.

To provide some information on the characteristics of current participants in IRAs and 401(k) plans, Table 1 presents information on the age-specific prevalence of IRA ownership, and the rate of $401(k)$ participation in 1991 . These patterns are important background information given the data that will be presented below on the asset allocation of IRA and 
401 (k) participants. The data in the upper panel show that IRA participation rises with income and also with age. More than 40 percent of those between the ages of 55 and 65 have Individual Retirement Accounts, while only one quarter of those in a cohort twenty years younger have such accounts. The prevalence of IRAs is also sharply rising in income. The data on IRAs only indicate that a respondent has an account, not that contributions to such accounts were made in the survey year (1991). Thus it is possible that many of the perticipants opened these accounts before 1986, and have continued to hold the accounts without making contributions. ${ }^{3}$ Between 1986 and 1989, IRA contributions fell by roughly seventy-five percent. Some IRA holders are also likely to have created these accounts as vehicles into which to roll-over distributions from other tax-qualified retirement saving plans.

The center panel of Table 1 shows the probability of participating in a $401(\mathrm{k})$ plan. These probabilities vary relatively little by age, but once again rise substantially as income increases. As the data in the lower panel of Table 1 show, most of the income-dependence in $401(k)$ participation rates arises from varying rates of $401(k)$ eligibility, not from variation

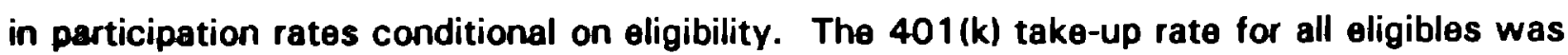
70.8 percent in 1991 , substantially higher than the IRA participation rate for all but the highest income categories. It is possible that some of the participation in $401(\mathrm{k}) \mathrm{s}$ at lower income level reflects employer "helper" contributions that are made to include these employees in the plan and thereby to satisfy nondiscrimination rules for plan qualification.

We have also explored the prevalence of IRAs and various salary reduction plans in the Health and Retirement Survey (HRS), an ongoing survey of 12,600 individuals between the

\footnotetext{
${ }^{3}$ Some individuals may have multiple Individual Retirement Accounts, and make contributions in a given year to only one of these accounts.
} 
ages of 51 and 61 in 1992. The HRS questionnaire does not ask the same questions as the SIPP survey instrument, but it is nevertheless possible to estimate the prevalence of IRAs, defined contribution plans at the respondent's current job and from former jobs, as well as the prevalence of other tax-deferred saving vehicles such as 401 (k)s and 403 (b)s. The results are shown in Table 2.

The HRS findings are broadly consistent with those from the SIPP. For IRAs, the HRS data suggest that 36.1 percent of respondents have an IRA or an IRA and a $401(\mathrm{k})$ plan. Of the 8.4 percent of the respondents who are shown as "other multiple" in Table 2, 7.7 percent report having an IRA, so the total IRA participation is 43.8 percent for the HRS respondents. This compares with 35.3 percent for the 45-54 age group, and 43.8 percent for the 55-64 age group, in the SIPP data shown in Table 1. With respect to 401 (k) plans, the HRS data suggest that 14.8 percent of respondents participate; this percentage is somewhat lower than in the SIPP sample.

The SIPP and HRS data suggest that IRAs and $401(\mathrm{k})$ participation is not randomly distributed across the income distribution, but tends to increase with age and income. ${ }^{5}$ The sample of participants in these plans will therefore provide more information an the investment decisions of older, higher-income groups that are more likely to participate in these plans than on younger, low-income workers who are not. We address these issues in our subsequent analysis by stratifying households by age and income where possible.

\footnotetext{
4Poterba, Venti, and Wise (1995b) analyzed the HRS data in studying the utilization of lump-sum distributions from defined contribution plans.

${ }^{5}$ This is why studies of the saving effects of these retirement saving plans, such as Poterba, Venti, and Wise (1995a), stratify households by income level in carrying out saving comparisons.
} 


\section{Asset Allocation Patterns in Retirement Saving Plans}

This section presents information on the asset allocation of retirement saving plans. We begin by presenting survey-based information from the 1992 Survey of Consumer Finances, which asked respondents about investment patterns in IRAs, salary-reduction arrangements (SRAs) such as employer thrift plans, and $401(k)$ and traditional defined contribution pension plans (DC plans). We then present information from other sources, such as industry association tabulations on asset allocation decisions in IRAs and 401 (k) plans or specialized tabulations on esset allocation in the federal government's Thrift Saving Plan. Each of these different methods of obtaining information provides some evidence on current patterns of household asset allocation.

\subsection{Summary Information from the Survev of Consumer Finances}

The Survey of Consumer Finances (SCF) is a stratified random sample of U.S. households administered by the Federal Reserve Board. It is designed to gather detailed information on assets, liabilities, and demographic characteristics. To collect useful information on asset holdings, in light of the skewed distributions of many types of financial and real assets, each survey oversamples high income households. Each SCF contains an area-probability sample, which is a stratified random sample of households chosen from the population at large, and a stratified random sample of households drawn from a set of highincome tax returns. Both samples are surveyed using the same questionnaire, but missing value imputations in the public release versions are typically done separately. We use the most recent publicly-available survey, the 1992 SCF, to provide some information on asset allocation patterns in IRAs, $401(k)$ and $403(b)$ plans and other supplemental retirement accounts, and traditional defined contribution pension plans. The latter category in the SCF 
includes profit sharing or thrift plans and Employee Stock Ownership Plans (ESOPs).

Table 3 presents data on the fraction of assets in each of these retirement saving vehicles that are held in the form of corporate stock or mutual funds that invest primarily in corporate equities. ${ }^{7}$ The data are stratified by age in each case. The results show that approximately half of the assets in each of these accounts are held in corporate equities. At least for the individuals who are currently participating in these plans, it therefore appears that equity investment is viewed as an important aspect of accumulating assets for retirement. There are apparent differences in age-specific rates of equity ownership, with those over the age of 65 showing a lower equity fraction of IRA and SRA assets than comparable, but younger, individuals.

One difficulty in evaluating results such as those in Table 3 is that it is not clear what "theory" suggests we should find. There is no presumption that households of different ages should allocate the same fraction of their portfolio to equities. Bodie, Merton, and Samuelson (1992) develop an argument for reducing equity exposure as households age, and Samuelson (1989, 1990) discusses arguments for age-related variation in equity holding." Similarly, if households view their retirement accounts as part of a broader portfolio selection problem, one must analyze their overall investment decisions rather than allocation choices in these

\footnotetext{
The critical limitation of the SCF for studying this question, and a limitation of most survey data on retirement saving plan asset allocation, is that we do not know whether the retirement plan is self-directed. In some plans the plan sponsor may restrict asset allocation choices, for example by contributing all employer contributions to a pension plan to an account that holds only company stock.

'A related discussion and data summary may be found in the General Accounting Office (1996) study.

Even if households reduce equity exposure as they age, they may still want to hold equities after retirement because of the long life expectancy for many couples at retirement age.
} 
accounts alone. For individuals who face high marginal tax rates on interest income, for example, holding bonds rather than equities in their tax-favored retirement accounts may provide higher after-tax portfolio returns than alternative portfolio profiles.

\subsection{Other Sources of Information on IRA and 401(k) Asset Allocation Patterns}

In addition to survey information like that contained in the SCF, it is also possible to obtain data on asset allocation in IRAs and some other categories of retirement saving accounts from financial industry sources that monitor aggregate trends. Information of this type is presented for IRAs in Table 4, which shows data for 1989 and 1994. These data are disaggregated by the type of financial institution holding the IRA, but this provides a reasonable guide as to the assets held in the account. In 1989, commercial banks, credit unions, and thrift institutions accounted for $49.1 \%$ of all IRA assets. IRAs with these institutions were presumably invested in various fixed-income securities. Adding money market mutual funds and bond and income funds to these assets brings the total of fixedincome assets to $62.2 \%$. By 1994, the share of assets in these fixed-income categories had declined to $40.3 \%$. Equity mutual funds increased from $11.5 \%$ to $16.7 \%$ of IRA assets during this period, but the sharpest increase (from $18.1 \%$ to $34.6 \%$ ) was in "other selfdirected" assets. The data from the Survey of Consumer Finance suggest that various types of equity investment are likely to account for a substantial share of this category.

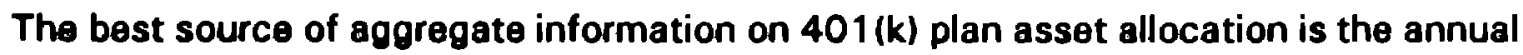
set of IRS Form 5500 filings, most recently published for 1992 data in Department of Labor (1996). These show $401(k)$ plan assets of $\$ 510.2$ billion, with employer securities (presumably company stock) worth $\$ 88.2$ billion, or $17.3 \%$ of the total. Identifiable interestbearing assets, which include interest-bearing cash, CDs, corporate and government debt, and 
various loans, totalled $\$ 60$ billion, or $11.2 \%$ of the total. Common and preferred stock direct holdings totalled $\$ 45.7$ billion, or $9 \%$ of all assets. "Indirect investments," which are not identified by the nature of the underlying securities on Form 5500, are an important and unallocated category, including $\$ 101.9$ billion in "interests in master trusts," $\$ \mathbf{4 7 . 2}$ billion in registered investment companies, $\$ 75.6$ billion in insurance company general accounts, and $\$ 26.9$ billion in unspecified general investments.

The coarse information on form $\mathbf{5 5 0 0}$ has led to a number of private sector surveys of 401 (k) plan asset allocation. Such surveys are based on a subset of existing 401 (k) plans, and whether the plans included in each survey are representative of the broader population of plans is difficult to evaluate. Nevertheless these surveys provide an important source of evidence on the evolving pattern of 401 (k) asset allocation. Table 5 presents this type of data from two different surveys over the 1988-1995 period. These surveys, by Access Research and IOMA, have been conducted periodically since the late 1980 s or early 1990s. The surver findings suggest that there are some differences in results across the two survers, even in a given year, but the trends in two surveys over time are similar.

There are several noteworthy findings in Table 5. First, consistent with the Survey of Consumer Finance evidence, approximately half of $401(k)$ assets are currently invested in equities. However, the data presented here suggest that a higher fraction of $401(\mathrm{k})$ assets than other equity assets are invested in shares the company where an individual works. There is a correspondingly lower investment fraction in diversified national or international equity portfolios. The Access Research findings suggest $43 \%$ in corporate equities or company stock, with another $14 \%$ in balanced funds that would include some equity holdings. The IOMA findings suggest $55 \%$ in corporate equities, without further detail as to breakdown. The data from the Form 5500s, and the Access Research results, suggest that one important 
feature of $\mathbf{4 0 1}(\mathrm{k})$ plans is their substantial holdings of company stock. One reason for the significant level of such holdings is that employers sometimes channel their matching funds into accounts that are limited to holding corporate stock. In such cases employees may have some discretion in the investment of their own contributions, but have no control over the investment of employer contributions.

The second significant finding in Table 5 is that the share of $401(k)$ assets held in equity securities has increased substantially during the last half decade. Both the Access Research and the IOMA data suggest a sharp increase, with an 8 percent increase between 1992 and 1995 in the latter. This trend toward equity investment coincides with a decline in the share of Guaranteed Investment Contracts (GICs). The trend toward greater equity holdings may be the result of several factors: high equity returns raising the relative asset share of these securities, even if $\mathbf{4 0 1 ( k )}$ investors hold fixed their contribution allocation between equities and fixed income assets; declining nominal long-term interest rates, which have made GICs less attractive in the eyes of some investors; rising expectations of future equity returns, driven in part by extrapolative expectations and the recent period of strong equity returns.

The $401(k)$ asset allocation choice reflects two decisions: one by employers with regard to which investment options to offer, and a second by emplovees with respect to which investments to choose, given the available menu. Broad choice is now the rule, rather

\footnotetext{
'How individuals adjust their portfolio holdings to the existence of corporate defined benefit plan accounts held in company stock is an important unresolved issue. If individuals do recognize the employer's contribution, and pursue the imperfect hedging strategy of reducing their holdings of equity in general to offset the holding of employer shares, then the data suggest that individuals seek to hold roughly half of their assets in equities. If they do not consider the employer contributions, however, then it becomes appropriate to subtract this $20 \%$ of the value of $\mathbf{4 0 1}(\mathrm{k})$ assets from both the equity holdings and from the total value of these accounts. This suggests an equity share of slightly less than $40 \%$.
} 
than the exception, in 401 (k) plans. A recent RogersCasey (1996) survey found that only 1 percent of $\mathbf{4 0 1}$ (k) participants worked at firms with only a single investment option; 2 percent had two options, 6 percent three options, 9 percent four options, 18 percent five options, and 74 percent had six or more investment options. More than three quarters of $401(\mathrm{k}) \mathrm{s}$ offer an actively managed domestic equity investment vehicle, compared with 62 percent offering a money market fund, 61 percent offering a stable value fund, and 60 percent offering a U.S. balanced fund.

Table 6 presents information from the 1994 Access Research (1995) survey that shows both the availability of various investment options, and the use of these options given their availability. The data show that roughly $60 \%$ of individuals make at lesst some use of equity mutual funds when they are included in the opportunity set. Index funds and international equity funds are somewhat less popular, conditional on availability, than various types of growth funds. The data in Table 6 shed some light on the role of company stock (shares in the firm that employs the workers who participate in the plan) in 401 (k) plans, and suggests that some individual purchase company stock even though they are not required to do so by plan regulations. ${ }^{10}$ While less than half of the $401(k)$ participants surveyed had a company stock investment option in their 401 (k) plan, nearly 60 percent invested in company stock if this option was available. Company stock, GICs, and various growth-oriented equity mutual funds have the three highest takeup rates conditional on availability.

All of the foregoing data focused on aggregate allocation patterns in $401(\mathrm{k})$ assets, with no information on how individuals in different circumstances choose to allocate their assets. Table 7 presents information drawn from Goodfellow and Schieber's (1996) analysis

\footnotetext{
19 Whether employers exert tacit pressure for purchasing company stock in retirement accounts is an open issue.
} 
of almost 36,000 participants in twenty-four $401(\mathrm{k})$ plans." The table shows the fraction of $401(\mathrm{k})$ plan assets held in each asset category, by the age of plan participant. ${ }^{12}$ The data $^{2}$ show clear asset allocation differences across age groups. Younger plan participants are more likely to invest their $\mathbf{4 0 1}(\mathrm{k})$ assets in stock funds or company stock than are older workers. The fraction of assets in the three equity categories, domestic or international stock funds and company stock, declines from 52.9 percent for those aged 21-30, to 30.3 percent for those in their fifties and 13.4 percent for those over the age of $60 .^{13}$

Table 8 presents analogous information with participants disaggregated by income level. Since the analysis is based on $\mathbf{4 0 1}(\mathrm{k})$ plan records, income in this context represents wage and salary income from the plan-sponsoring firm, not total family income. As with age, there is a clear pattern in asset allocation by income category. Higher income earners allocate

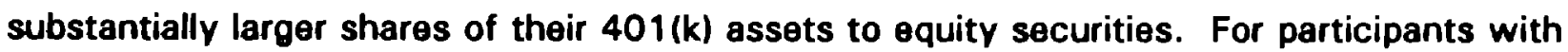
incomes between $\$ 15,000$ and $\$ 25,000$, for example, 29.9 percent of $401(\mathrm{k})$ assets are held in equities, compared with 59.4 percent for those with incomes between $\$ 75,000$ and $\$ 100,000$, and 64.5 percent for those with incomes above $\$ 100,000$. The fraction of assets

\footnotetext{
"The Employee Benefit Research Institute (1996b) presents a related analysis of the asset allocation choices of investors in three large $401(\mathrm{k})$ plans. The results are broadly consistent with those from the large sample of plans analyzed by Goodfellow and Schieber (1996).

${ }^{12}$ The entries in the total column raise some questions about the comparability of this sample with the $401(\mathrm{k})$ universe. The share of assets held in company stock is substantially

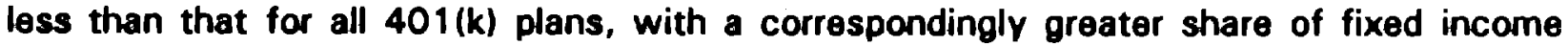
investments.

${ }^{13}$ Goodfellow and Schieber (1996) also present data on the fraction of 401 (k) participants who allocate none of their contributions to equity investments (31.2 percent of the total sample, with some age variation as suggested by 29.2 percent for those aged 21-30, 30.6 percent for those between 41 and 50 , and 52.3 percent for those over 60l, and the fraction who allocate more than 60 percent of their contributions to equities 136.7 percent for the 2130 group, 30.7 percent for those $41-50,18.8$ percent for those $60+$, and 31.4 percent of the entire samplel.
} 
held in balanced funds also increases with income, while the allocation to fixed income funds falls roughly in half between the lowest and highest income categories.

The relationship between income and the share of contributions allocated to equities in the Goodfellow and Schieber (1996) date parallels our earlier finding from the Survey of Consumer Finances, but the link between perticipant age and contribution mix (Table 6) is much stronger than in the Survey of Consumer Finances. This may be due to the difference between the definition of "age" in the SCF and in data bases with information on individuals. $^{14}$ Because SCF respondents are asked about the financial status of their household, participation in a $401(k)$ means that someone in the household has a $401(k)$ account. Household age is determined by the age of the household head, with is a noisy measure of the age of actual participants. This could weaken the relationship between age and the behavior of participants as measured in the SCF. ${ }^{16}$

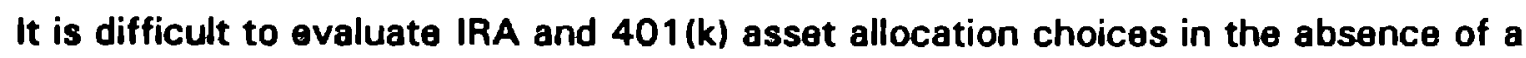
benchmark, derived either from theoretical analysis of the return distributions and consumption needs confronting investors, or from other sources. One possible comparison is the current asset mix in these plans relative to that in defined benefit pension plans. In 1994. Bernstein Research (1995) reports that these plans held $46 \%$ of their assets in domestic equity, $11 \%$ in international equities, $28 \%$ in bonds, $5 \%$ in GICs, $3 \%$ in real estate, and $7 \%$ in other essets. IRA and $401(\mathrm{k})$ investment patterns thus reflect a much greater

\footnotetext{
14Bajtelsmit and VanDerhei (1996) analyze asset allocation decisions in a single large defined contribution plan, and find some evidence that both younger workers and older workers are more likely to hold assets in fixed-income instruments than are middle-aged workers. This result mey be driven by their use of a quadratic specification in modelling the age-dependence of asset holdings, or by special characteristics associated with the defined contribution plan under analysis.

${ }^{16}$ Another possibility is that the Goodfellow-Schieber data set reflects an unrepresentative sample of $401(k)$ participants, but we have no way to address this issue.
} 
holding of GICs, and a somewhat lower level of equity investment, but they are not dramatically different from the asset allocations of defined benefit pension assets. ${ }^{10}$

\section{Asset Allocation in Twe Retirement Saving Systems}

The discussion so far has considered asset allocation in Individual Retirement Accounts, which are available (at least in some form) to all individuals with current earned income, and $401(\mathrm{k})$ plans, which are broadly available in the private sector. In this section we draw on the experience of two more specialized retirement saving programs, the Thrift Saving Plan for federal government employees and the TIAA-CREF system for employees of educational institutions, to address similar issues of asset allocation.

\subsection{Asset Allogation Experience in the Federal Emplovee Thrift Savings Plan}

The federal government's retirement system includes an option for voluntary contributions to the federal thrift savings plan (TSP), which is structured along the lines of most $401(k)$ plans. In early 1995, the TSP had two million participants and nearly $\$ 27$ billion under management, according to Hinz, McCarthy, and Turner (1996). Employee contributions to the TSP are made on a pre-tax basis. The federal government matches, dollar-for-dollar, employee TSP contributions up to three percent of salary, and 50 cents-on-the-dollar for the next two percent of salary. Contributions to the TSP are constrained by the same contribution limits as $401(k)$ contributions at private sector employers, although there are no nondiscrimination rules constraining the distribution of contributions to the TSP.

Table 9 shows the percentage of workers choosing to make contributions to the TSP

\footnotetext{
${ }^{10}$ The merits of this comparison may be questioned on the grounds that defined benefit plan assets are managed to achieve objectives of an infinite-lived agent, the plan's corporate sponsor, and are insured by a government agency, the Pension Benefit Guaranty Corporation.
} 


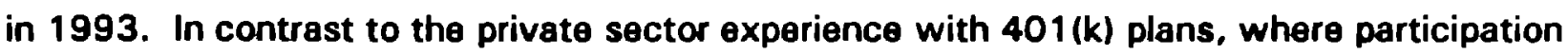
in these plans conditional on eligibility exceeds 60 percent even at low income levels (see Poterba, Venti, and Wise (1995a)), participation in the TSP is below 50 percent at income levels below $\$ 20,000$ per year, and rises to 96 percent at income levels above $\$ 70,000$. The federal government automatically contributes one percent of salary to the TSP for all employees; this is not considered "participation" in this table.

The federal Thrift Saving Plan historically offered more limited investment options than many private $401(\mathrm{k})$ plans. ${ }^{17}$ Until 1987, all TSP contributions had to be invested in a federal government securities fund. This requirement was gradually phased out between 1987 and 1991. Since 1991, TSP assets can be allocated between three different funds, without restriction. Participants are allowed to re-allocate assets that have accumulated from pre-1987 contributions, as well as to allocate new contributions, among three funds: a government securities fund which earns the average market return on marketable Treasury securities with more than four years to maturity, a large-capitalization stock fund that invests in the S\&P 500, and a fixed income fund that invests primarily in a Shearson Lehman Hutton commingled Government/Corporate bond index fund. The General Accounting Office (1995) reports that at the beginning of 1995, 70 percent of the assets in the federal thrift plan were invested in federal securities fund, while 6 percent were held in a commercial bond fund and 24 percent in the corporate equity fund. The equity fund is currently attracting a higher share of contributions (35 percent in August 1994) than its share of assets, but participants have apparently made little use of a post-1990 provision permitting re-allocation of funds that were contributed during the period when all contributions were directed to the government bond fund.

\footnotetext{
${ }^{17}$ yinz, McCarthy, and Turner (1996) provide an overview of federal Thrift Saving Plan.
} 


\subsection{Asset Allocation in TIAA-CREF}

TIAA-CREF is the retirement saving system for emplovees of colleges, universities, and some other nonprofit institutions. It includes university faculty as well as staff. Many TIAACREF participants, like employees of the federal government, are better educated than randomly-selected individuals in the population, so analysis of their retirement saving behavior may not be completely representative of all who might participate in a mandetory, economywide seving system. Nevertheless, one important benefit of analyzing the TIAA-CREF data is that we can obtain individual-level data as well as aggregate information on asset allocation choices.

Because TIAA-CREF is a financial service provider, individual data records suffer from the same limitations as participant records in $401(\mathrm{k})$ plans, notably the lack of information on demographic characteristics and household income. However, two special data bases, the 1993 Premium Paying Research Panel and the 1988 Participant Survey, have been collected in recent years, and each of these data bases has detailed information on individual attributes. Both survers include a set of questions about participant retirement and financial planning, and they provide valuable information for studying participant decisions. The decision we focus on is the choice between allocating funds to TIAA accounts, which are invested in portfolios of fixed-income instruments, and CREF accounts, most of which are invested in equities. $^{10}$

Table 10 presents information on the current asset allocation choices of TIAA-CREF participants, as well as the allocation of existing balances between CREF and TIAA accounts. In 1993, TIAA accounts attracted 38 percent of contributions (contributions to TIAA CREF

\footnotetext{
${ }^{10}$ Since 1988, CREF has offered a Money Market Account, and since 1990, CREF has offered a Bond Market Account. When the survey data were collected in 1988, however, virtually all CREF assets were invested in equities.
} 
are frequently referred to as premiums). ${ }^{10}$ There is a clear link between age, income, and the fraction of contributions allocated to fixed-income instruments. The TIAA share is 32 percent for those under the age of 35 . It rises to 38 percent for those between the ages of 45 and 54, and then to 53 percent for those over the age of 65 who are still making contributions to TIAA-CREF. The fraction devoted to TIAA declines by more than fifteen percentage points as we move from individuals with incomes of less than $\$ 25,000$ to those with incomes above $\$ 100,000$.

The fraction of total TIAA-CREF assets held in TIAA accounts is remarkably similar to the asset allocation mix of current contributions. This reflects the combined effect of an increase over time in the share of contributions that participants have allocated to CREF accounts, and the greater return on equities than on bonds. The first effect would cause the contribution share going to TIAA to fall below the share of existing assets held in TIAA accounts, while the second effect works in the opposite direction.

\subsection{Particioant-Level Evidence on Allocation Decisions in TIAA-CREF}

To further explore the factors that affect asset allocation choices, we obtained date from the 1988 TIAA-CREF Participant Survey. This unique data base has been used by Laitner and Juster (1996) to study the determinents of intergenerational altruism; the data are described in detail in Juster and Laitner (1990). In addition to information on the percentage of TIAA-CREF accumulation held in each type of account, drawn from participant records, the data base also includes information on participant and other family income, financial assets and other components of net worth, and various demographic characteristics. We use this

\footnotetext{
${ }^{19}$ CREF attracted 43 percent of premiums, with the other 19 percent of premiums allocated to hybrid accounts or other specialized accounts.
} 
information to estimate simple regression equations of the following form:

$$
\begin{aligned}
& \% \text { TIAA }=a_{0}+a_{1} \text { *AGE }+\sigma_{2} \text { *MARRIED }+\sigma_{3} \text { *FEMALE }+\sigma_{4} \text { *INCOME } \\
& +\Sigma a_{6, j} * E D U C_{1}+\Sigma a_{0, j} * W E A L T H_{j}+\epsilon .
\end{aligned}
$$

EDUC $_{\mathbf{i}}$ denotes a set of indicator variables for particular ranges of education, and WEALTH similarly denotes a set of indicator variables for net worth in various categories. Net worth is defined as the sum of all financial assets net of debts, plus the reported value of housing. other real estate, boats, autos, life insurance, trusts, and businesses owned. INCOME corresponds to family income, so it includes both income that the TIAA-CREF participant may earn outside the educational institution, as well as income earned by others in the household. The median asset share in TIAA for this sample is $\mathbf{4 3}$ percent, and the mean is 52 percent. These values are higher than in the 1993 data shown in Table 9, consistent with the view that TIAA-CREF participants have become increasinglv equity-oriented over time. ${ }^{20}$

Table 11 presents the results of estimating these regression models. The table shows three different specifications with respect to education and wealth. The only demographic variable that affects asset allocation in all three specifications is the gender of the respondent; women systematically invest approximately four percent more of their accumulation in TIAA accounts. ${ }^{21}$ Family income, education, and household net worth are also related to asset allocation choices. With respect to family income, the only category indicator that enters the equations in a statistically significant fashion is that for family income above $\$ 100,000$. Participants from such households allocate between five and seven percent less of their TIAA-

\footnotetext{
${ }^{20}$ Assets in CREF accounts can be transferred into a TIAA account, but once assets have been placed in a TIAA account, thoy may not be reallocated to a CREF account. This places constraints on the speed with which the aggregate TIAA-CREF portfolio can shift from bonds to stocks.

${ }^{21}$ This finding also appears in other data sets; see in particular Hinz, McCarthy, and Turner's (1996) analysis of data from the federal Thrift Savings Plan.
} 
CREF assets to TIAA than do participants from households with incomes below $\$ 50,000$ per year. These results are consistent with earlier evidence, for $401(k)$ plans and IRAs, suggesting that higher income households are more likely to choose equity investments. With respect to education, the only important distinction is between those TIAA-CREF participants with twelve or fewer years of schooling, and those with more than 12 years of schooling. The former group allocates more than ten percent more of its portfolio to TIAA than does the combined more educated group.

\section{3,4 Interpretation}

Similar asset allocation patterns emerge with respect to household net worth. Participants from households with net worth above $\$ 250,000$ allocate approximately four percent less of their TIAA-CREF accumulation to TIAA, but there are no statistically significant differences in the asset allocation patterns of participants from households with net worth below this level. The results in Table 11 support the evidence from other sources that suggest that high income, high net worth individuals are more likely to allocate retirement saving assets to equities than are their counterparts from lower-income, lower-net worth households.

Our ubiquitous finding that lower-income, less-educated individuals allocate a smaller share of retirement plan assets to equities can be interpreted in either of two ways. First, it is possible that these individuals are more risk averse than higher-income, better-educated individuals, and that they are choosing different asset allocations because of this underlying difference in preferences. The second, alternative, interpretation, is that these individuals do not correctly perceive the higher expected returns associated with equity investing, and that they are making an optimization error by holding too large a share of their portfolio in fixed- 
income assets.

One way to distinguish between these alternative views might involve studying how participant education affects asset allocation choices. If $401(\mathrm{k})$ and other retirement plan participants in low income classes choose to hold a higher fraction of their assets in equity after they have been exposed to information on portfolio returns, then the optimization error view may receive some support relative to the risk aversion explanation. The Employee Benefit Research Institute (1996a) reports that asset allocation is one of the most frequently covered topics in participant education programs at firms with $401(k)$ plans or similar retirement saving options. The impact of this education on asset choices is an important issue for further investigation. ${ }^{22}$

\section{Evidence on Annuity Demand}

The extent to which individuals would use the proceeds accumulated in mandatory saving accounts to purchase annuities is another important issue in evaluating and designing such plans. Relatively fow household survers explicitly inquire about income received from individual annuity contracts. The Health and Retirement Survey did include such a question, but since the respondents were typically in their fifties, it is not surprising that the resulting prevalence of annuity income, 1.57 percent, was low. ${ }^{23}$ Perhaps more relevant, in the HRS sample only 8.0 percent of respondents who had previously worked for an employer with a defined contribution plan reported that they had selected an annuity as the method of payout

\footnotetext{
${ }^{22}$ Milne, VanDerhei, and Yakoboski (1996) present some information on the asset allocation choices of individuals in $\mathbf{4 0 1}(\mathrm{k})$ plans with different types of participant education systems, but they do not report "before and after" asset allocation patterns.

${ }^{23}$ The mean annual annuity payout reported by those who indicate that they receive annuity income is $\$ 13,496$.
} 
for their accumulated DC plan assets. Other possible responses to this question included withdrawing the money, rolling it over into an IRA, and allowing it to accumulate.

\subsection{Would Current Retirees Choose to Purchase More Annuity Coverage?}

A more valuable source of information on potential annuity demand is the 1988 TIAACREF survey of annuitants, which parallelled the survey of TIAA-CREF contributors discussed above but was administered only to annuity recipients. ${ }^{24}$ Annuities are only one of the ways TIAA-CREF participants can withdraw their accumulated account balances. Although rare during the time period corresponding to this survey, participants could also choose lump sum payouts or withdrawals of several substantially equal payments. The 1988 survey focused only on those participants who had reached the distribution phase of their saving plan, and who had chosen the ennuity option. ${ }^{25}$ TIAA-CREF offers a variety of potential annuity options, including participating annuities (with a low guaranteed payout rate but historically substantial dividends) for TIAA participants and variable annuities based on a range of different portfolios for CREF participants.

One of the questions on the TIAA-CREF annuitant survey was "If you unexpectedly received $\$ 100,000$, what would you do with it?" Just over one quarter of the respondents, 26.5 percent, indicated that they would purchase an annuity. This fraction did not vary substantially as a function of respondent age. Roughly the same fraction, 24.5 percent, indicated that they would either spend roughly $\$ 16,000$ per year (which would exhaust the

\footnotetext{
${ }^{24}$ The asset allocation patterns between TIAA and CREF in the participant and annuitant surveys are similar. At the lowest education and net worth levels, there is a pronounced tendency for greater investment in TIAA rather than CREF.

${ }^{25}$ Some participants might have stopped contributing to TIAA-CREF, but not yet begun to withdraw their accumulation. They would not be included in the surver.
} 
windfall in about eight years), or $\$ 10,000$ per year (windfall exhausted in about twelve years. Thirty seven percent of the respondents indicated that they would consume only the income from the windfall, and about twelve percent reported that they would spend less than the annual income from this windfall.

It is important to recognize three features of the TIAA-CREF annuitant group that makes them special for the purpose of analyzing annuity demand. First, all of the survey participants have both a real annuity from Social Security and another annuity payout from TIAA-CREF. ${ }^{20}$ Their responses may consequently not describe the responses of retired households who do not have annuity coverage beyond Social Security, or the responses that would be observed if the current Social Security system were pared back.. Second, most of the respondents are drawn from the upper quintile of the U.S. income and wealth distributions (see Laitner and Juster (1996)), although they are not likely to represent the very highest income and wealth strata of the population. If the demand to bequeath assets is related to lifetime income, then this group may provide a guide to the annuity demands of only a part of the population. Third, the TIAA-CREF participants may have access to annuities on more favorable terms than individuals in the private marketplace, and may be assuming that they would purchase additional annuities on such terms.

While recognizing these limitations, we explored the factors that affect the respondent's answer regarding how a windfall would be allocated. ${ }^{27}$ Our approach follows

\footnotetext{
20TIAA-CREF participants who purchase standard annuities can choose between simple nominal annuities and "graded" policies in which the stream of payments is backloaded in part to offset the effects of inflation. Thus TIAA-CREF annuitants are not necessarily holding simple nominal annuities in addition to their Social Security real annuity.

${ }^{27}$ One difficulty with surveys of this type is "surveyor preference bias:" respondents attempt to provide what they believe the survey-taker believes is the "correct" answer. It is difficult to know how important biases of this type are likely to be in this data set.
} 
the regression strategy that we used above to investigate the share of assets that TIAA-CREF participants hold in TIAA accounts. We now estimate linear probability models for each of the possible responses to the questions on windfall use, illustrated for example by BUYANNUITY, which equals unity if the respondent indicated that he or she would purchase an annuity with the windfall proceeds:

$$
\begin{aligned}
\text { BUYANNUITY } & =\beta_{0}+\beta_{1} \text { *AGE }+\beta_{2} \text { "MARRIED }+\beta_{3} \text { *FEMALE }+\beta_{4} \text { "SOCSEC } \\
& +\beta_{3} \text { *KIDS }+\sum \beta_{0, j} \text { "EDUC }+\sum \beta_{7, j} \text { "WEALTH }+\epsilon .
\end{aligned}
$$

The family income variable from the earlier specification is now replaced with a variable measuring the household's Social Security benefits, which proxy for a ranking of lifetime labor income. We also augment the earlier specification with a variable indicating whether or not the household has children, since that may be a proximate determinant of annuity demand.

The results of estimating this equation are shown in Table 12, and they suggest that it is difficult to find simple patterns in the responses to these questions. The only robust empirical finding is that TIAA-CREF participants with children are less likely to choose an annuity or a rapid "spend-down" plan, and more likely to pursue policies that preserve their capital, than are participants without children. There is some evidence that married respondents are less likely to annuitize a windfall than are other respondents; this may indicate a belief that the question is limited to individual annuties, which terminate at the death of the annuitant (a married couple could also choose a joint and survivor's annuity). There is also weak evidence that respondents in the lower portion of the net worth distribution are more likely to say that they would spend thoir windfall than are those in the higher parts of the distribution. One puzzling feature is that the prevalence of spending-down among those with the lowest net worth, less than $\$ 50,000$, is lower than among those in the $\$ 50-\$ 250,000$ net worth range. The estimates in the last column of Table 12, which correspond to the 
response that recipients would spend less than the current income from the windfall, do not show any robust patterns.

\subsection{Current Annuitization Patterns_at TIAA-CREF}

One issue that TIAA-CREF data can enlighten is the type of annuity contracts that individuals purchase when they do purchase annuities. TIAA-CREF retirement annuity contracts can be written on a single life or two lives (typically to provide for the participant and a spouse), and these contracts can be written as simple annuities, in which the payouts cease when the annuitant(s) die, or as annuities with guarantees that payments will be made for a certain period, even if the annuitant(s) do not survive for this period. ${ }^{2 \theta}$ In a standard lifecycle setting without bequest motives, the simple annuity, which provides a higher monthly payout in each period when the annuitant is alive than any of the guaranteed options, dominates the other choices. ${ }^{20}$

Table 13 presents information on the choice of annuity policy by TIAA-CREF participants who contracted for annuities in 1978 and in 1994. The table shows both singlelife and joint-life annuity policies. King (1996) reports that in 1978, 44 percent of the annuitios contracted for by male TIAA-CREF participants were single-life policies, compared with 26 percent of such policies in 1994. For women, the respective percentages of singlelife policies were 81 percent (1978) and 68 percent (1994).

The table shows that simple annuities without guarantee provisions account for only

\footnotetext{
20"Years-certain" annuities are life annuities with a guarantee that payments will be made for at least some number of years.

${ }^{20}$ This assumes that the available annuity policy is actuarially fair for the potential purchaser. In practice, since TIAA-CREF uses a unisex life table to price annuities, it could bo the case that policies other than a simple annuity are optimal for some participants.
} 
about one third of all single annuity policies, but less than fifteen percent of joint life policies. Policies with certain payout periods of fifteen years or more account for more than one third of the single-life annuities chosen by both men and women in 1994, and they account for nearly two-thirds of the two-life policies. Since the guarantee provisions in annuity contracts only become operative when the annuitant dies, in the case of single-life policies, or when both annuitants die, in the case of two-life policies, the widespread choice of annuities with guarantees casts doubt on the value of the simple lifecycle model as a starting point for describing household annuity demand.

\subsection{Theoretical Estimates of the Utility Gain from Annuitization}

To provide some perspective on the utility consequences of choosing to annuitize a given amount of wealth, we present illustrative calculations similar to those in Kotlikoff and Spivak (1981) and Friedman and Warshawsky (1990). We consider an individual who derives utility from consumption each month according to a standard iso-elastic utility function, $U_{t}=$ $\left(C_{t}{ }^{1-1}-1\right)(1-\beta)$, where $\beta$ is the coefficient of relative risk aversion. When $\beta=1$, this utility function yields the special case of logarithmic utility. We assume that an individual faces a probability of death each month that corresponds to the annual mortality rates reported in the 1996 Social Security Actuary's cohort life table for men born in 1930 (i.e., 65-year-olds in 1995). We assume that no one lives beyond age 115, and that lifetime expected utility for a man aged 65 is given by

$$
V=\sum_{t=65}^{115} P_{1}^{*}(1+\delta)^{-t * U\left(C_{1}\right)}
$$

where $P_{1}$ denotes the survival probability (to age $t$ ) for a sixty-five year old white man and $\delta$ is the individual's time preference rate. 
We first compute the expected lifetime utility associated with a "home-made annuitization" policy that involves consuming an amount in each period that equals current wealth divided by life expectancy. ${ }^{30}$ This implies that wealth evolves according to:

$$
W_{t+1}=(1+r) W_{1}-\left(1 / L_{1}\right) \cdot W_{1}
$$

where $r$ is the real rate of return. We essume that an individual has accumulated assets of 100 at age 65, find the value of $V$ (which we denote $V_{\text {hamemedo }}$ ) that corresponds to this consumption strategy.

Next, we assume that the individual can purchase an actuarially fair real annuity at age 65. We find the level of wealth at age 65 that would generate the same lifetime expected utility as the home-made annuity applied to wealth of 100 at age 65 . The ratio of this wealth to 100 indicates how much the wealth of the 65 -year-old could reduced, while leaving him at the same lifetime expected utility level, if he had access to an actuarially fair annuity market. We perform a similar calculation assuming that only nominal annuities are available, but again maintaining the assumption that these policies are actuarially fair.

Finally, we consider the effect of allowing for pre-existing real annuty policies in this setting. We assume that the 65-year-old man has both 100 in accumulated assets and the claim to a real annuity with an expected present value of 100; that is, half his wealth is annuitized. We then repeat the calculation allowing this individual to purchase a real or nominal annuity, and find the reduction in wealth that would lead to the same expected utility level if the annuity market were available.

\footnotetext{
${ }^{30}$ This does not represent the optimal consumption policy in the presence of lifetime uncertainty, except in special cases. When period-by-period utility is given by $U=\log c_{t}$ and the individual's time preference rate is zero, for example, the optimal consumption profile involves consuming wealth/(life expectancy) in each period. We focus on this consumption rule even in cases when it is not optimal because it is a simple rule, analogous to some withdrawal rules from retirement saving accounts such as IRAs, that individuals might easily implement.
} 
Table 14 presents the results of these calculations. The upper panel considers the case in which real annuities are available in the private market, and the lower panel considers the cese of nominal annuities. The first entry, for the $\log$ utility $(\beta=1)$ case, shows that with a three percent real interest rate and an annual discount rate of one percent, with no "preexisting" annuity, an individual would receive the same lifetime expected utility if he had wealth of 100 and no access to a real annuity market, or wealth of 64.0 and access to such a market. A 65-year-old man would be prepared to give up 36 percent of his wealth if he could purchase a real annuity rather than consume according to the reciprocal life expectancy rule. This finding, and the other results in the table for different parameter values, is broadly consistent with the results from the Kotlikoff and Spivak (1981) study. Higher risk aversion values increase the share of wealth that the individual would be prepared to give up to obtain access to an actuarially fair annuity market. ${ }^{31}$

The lower panel of Table 14 presents results for nominal rather than real annuities. The wealth equivalent results are similar to those for the real annuity case, although individuals would not be prepared to forego as much wealth if they could purchase nominal as if they could purchase real annuities. The effect of allowing for a pre-existing real annuty stream on the wealth equivalent measure is small, as can be seen from the differences botween the wealth equivalents in the first and second columns of Table 14.

These findings, while based on a stylized model, generally suggest that individuals receive substantial expected utility benefits from purchasing annuity contracts, at least in standard models. They draw attention to the limited fraction of TIAA-CREF annuitants who

\footnotetext{
${ }^{31}$ Further analysis of the utility gain from annuitization, considering the case of married couples as well as individuals, along with updated information on the actuarial present discounted value of currently-available individual annuity contracts, may be found in Mitchell, Poterba, and Warshawsky (1996).
} 
report that they would use a lump sum windfall to purchase an additional annuity.

\section{Conclusions and Extensions}

More than half of U.S. households between the ages of 51 and 61 currently participate in some form of self-directed retirement saving account. The financial management decisions of households with these accounts can provide some evidence on the how households might manage funds in a mandatory private saving system. We consider two aspects of financial management: asset allocation between stocks and bonds, and demand for annuities. With respect to the choice between stocks and bonds, we find that the aggregate fraction of $401(k)$ or IRA assets that are held in stocks is smaller, by approximately ten percentage points, than the equity fraction held by defined benefit pension fund managers. One notable feature of $\mathbf{4 0 1}(\mathrm{k})$ investment patterns is that they involve more holdings of own-company stock, and less investment in diversified portfolios of common stocks or international equities, than defined benefit plan portfolios. The share of $\mathbf{4 0 1} 1(\mathrm{k})$ and IRA assets allocated to equities, either via direct stock holding or through investment with intermediaries such as mutual funds, has increased significantly since the late 1980s. There are clear age-related and incomerelated patterns in aseet ellocetion: higher income households, and younger participants in retiremant saving plans, tend to hold a higher fraction of their assets in equities.

While these findings provide some evidence on asset allocation, they must be interpreted with caution for two important reasons. First, plan participants do not have complete investment discretion with respect to all assets in $401(k)$ plans, as they do with assets in Individual Retirement Accounts. Some $401(\mathrm{k})$ plans involve restrictions on asset choice, such as rules that employer contributions must be invested in employer stock. A related issue may arise in analyzing allocations for TIAA-CREF participants, some of whom 
face restrictions on the allocation of account inflows. Asset allocation patterns in IRAs may therefore provide a better indicator of unconstrained asset choice than decisions in existing employment-linked retirement saving plans.

A second difficulty in interpreting existing asset allocation decisions is that these decisions are made in an environment in which individuals expect to receive a real annuity, Social Security, which provides a floor on their consumption opportunities. Because some mandatory saving plans would scale back at least part of the existing Social Security system, it is possible that portfolio allocation decisions in such an environment would differ from those under the current system. This is an issue that can be analyzed under specific assumptions about the nature of individual's utility functions, the distribution of returns available to them, and the nature of Social Security.

This paper also presents some evidence on the demand for annuities by participants in the TIAA-CREF system, which provides retirement benefits for employees of educational institutions. Roughly one quarter of TIAA-CREF annuitants in the late 1980s, a group of individuals who already receive income from annuities, indicated that if they received a $\$ 100,000$ windfall, they would use these funds to purchase an additional annuity. Our andysis of a cross-sectional survey of those TIAA-CREF annuitants reveals fow strong correlates of this demand for additional annuities; married individuals are less likely to demand an additional annuity, and there is weak evidence that those with higher levels of net worth would be less likely to annuitize a windfall.

An important issue, that we have unfortunately been unable to find data to analyze, concerns the choice between annuities and other payout options by individuals who have accumulated assets in retirement saving plans. Participants in the Health and Retirement Survey, who were between the ages of 51 and 61, report that in eight percent of the cases 
when they left previous employers who had offered defined contribution plans, they chose to distribute plan assets by purchasing an annuity. This sample is too young to provide a clear perspective on the decisions made by individuals who reach retirement with substantial assets accumulated in a self-directed retirement saving account.

Even if it were possible to accurately measure the fraction of assets that are annuitized in this way, it is not clear how this information would bear on individual choices under a system of mandatory saving accounts. For precisely the reasons noted above, any proposal that scales back the real annuity associated with the existing Social Security system may affect individual demand for annuities. It is not clear what model to use in evaluating this issue. In simple life-cycle models, individuals with access to actuarially fair annuity markets should annuitize all of their wealth at retirement. However, these models may not provide a realistic guide to individual behavior. In models with bequest motives, private annuity markets that do not offer actuarially fair annuities, and uncertainty regarding future health risks and associated consumption needs, individuals might choose not to fully annuitize. Analyzing how individuals would decide between annuities and other distribution options requires a model that incorporates these features. In addition, as Diamond (1994) notes, one of the key questions about a system of privately-managed saving accounts is what annuity policies will be offered by private insurers in this setting. Considering general equilibrium effects in the annuity market complicates the analysis even further. 


\section{REFERENCES}

Access Research, 1995, Marketplace Dynamics. Windsor, CT: Access Research,Inc.

Bernstein Research, 1995. The Future of Money Management in America: 1995 Edition. New York: Sanford C. Bernstein \& Co.

Bajtelsmit, Vickie L. and Jack L. VanDerhei, 1996, "Risk Aversion and Pension Investment Choices," in Michael Gordon, Olivia Mitchell, and Marc Twinnoy, eds., Positionina Pensions for the Twenty-First Century (Philadelphia: University of Pennsylvania Press). Bodie, Zvi, Robert Merton, and William Samuelson, 1992, "Labor Supply Flexibility and Portfolio Choice in a Life-Cycle Model," NBER Working Paper 3954.

Diamond, Peter, 1994, "Privatization of Social Security: Lessons from Chile," Revista de Analisis Economico 9, 21-33.

Diamand, Peter, and Salvador Valdes-Prieto, 1994, "Social Security Reform," in B. Bosworth, R. Dornbusch, and R. Laban, eds., The Chilean Economy (Washington: Brookings Institution).

Employeo Benefit Research Institute, 1996a, "Participant Education: Actions and Outcomes," EBR Issue Brief 169. Washington: Employee Benefit Research Institute.

Employee Benefit Research Institute, 1996b, "Worker Investment Decisions: An Analysis of Large 401(k) Plan Data," EBRI Issue Brief 176. Washington: Employee Benefit Research Institute.

Feldstein, Martin S., 1996, "The Missing Piece in Policy Analysis: Social Security Reform," NBER Working Paper 5413, 1996.

Friedman, Benjamin M. and Mark J. Warshawsky, 1990, "The Cost of Annuities: Implications for Saving Behavior and Bequests," Quarterly Journal of Economics 105, 135-154.

Goodfellow, Gordon P. and Sylvester J. Schieber, 1996, "Investment of Assets in Self- 
Directed Retirement Plans," in Michael Gordon, Olivia Mitchell, and Marc Twinney, eds., Positioning Pensions for the Twenty-First Century (Philadelphia: University of Pennsylvania Press).

Hinz, Richard P., David D. McCarthy, and John A. Turner, 1996, "Are Women Conservative Investors? Gender Differences in Participant-Directed Pension Investments," in Michael Gordon, Olivia Mitchell, and Marc Twinney, eds., Pesitionino Pensions for the Iwenty-First Century (Philadelphia: University of Pennsylvania Press).

Ibbotson Associates, 1995, Stocks, Bills, Bonds, and Inflation; 1995 Yearbook. Chicago: Ibbotson Associates.

Investment Company Institute, 1995, Mutual Fund 1995 Fact Book. Washington: Investment Company Institute.

Juster, F. Thomas and John Laitner, 1990, "The TIAA-CREF Data Base: A Special Purpose Deta Set for the Analysis of Life-Cycle Saving Behavior," working paper, Institute for Social Research at the University of Michigan.

King, Francis, 1996, "Trends in the Selection of TIAA-CREF Life-Annuity Income Options, 1978-1994," ILAA-CREF Research Dialogues (forthcoming).

Kotlikoff, Laurence J. and Avia Spivak, 1981, "The Family as an Incomplete Annuities Markot," Journal of Political Economy 82, 372-391.

Laitner, John and F. Thomas Juster, 1996, "New Evidence on Altruism: A Study of TIAACREF Retirees," American Economic Review 86 (September), 893-908.

Milne, Deborah, Jack VanDerhei, and Paul Yakoboski, 1996, "Participant Education: Actions and Outcomes," EBRI Issue Brief 169 (Washington, DC: Employee Benefit Research Institute).

Mitchell, Olivia M., James M. Poterba, and Mark J. Warshawsky, 1996, "New Evidence on 
the Valuation of Individual Annuity Contracts," in preparation.

Poterbe, James M., Steven F. Venti, and David Wise, 1994a, "Targeted Retirement Saving and the Net Worth of Elderly Americans," American Ecenomic Review 84 (May 1994), 180-185.

Poterbe, James M., Steven F. Venti, and David Wise, 1994b, "401(k)s Plans and TaxDeferred Saving," in D. Wise, ed., Studies in the Economics of Aaing. Chicago: University of Chicago Press, $105-138$.

Poterba, James M., Stoven F. Venti, and David Wise, 1995a, "Do 401(k) Contributions Crowd Out Other Personal Saving?, Journal of Public Economics 58 (September 1995), 1-32.

Poterba, James M., Steven F. Venti, and David Wise, 1995b, "Lump Sum Distributions from Retirement Saving Plans: Receipt and Utilization," NBER Working Paper 5298.

RogersCasey and Institute of Management and Administration, 1995, RogersCasey/lOMA 1995 Defined Contribution Survay. Derien, CT: RogersCasey.

Samualson, Paul A., 1989. "A Case at Last for Age-Phased Reduction in Equity," Proceedings of the National Academy of Sciences 86 (November), 9048-9051.

Samuelson, Paul A., 1990, 'Long-Run Risk Tolerance When Equity Returns Are MeanRegressing: Pseudoparadoxes and Vindication of 'Businessman's Risk'," in W. Brainard, W. Nordhaus, and H. Watts, eds., Macroeconomics, Finance, and Economic Policy: Essays in Honor of James Tobin. Cambridge: MIT Press.

Siegel, Jeremy J., 1994, Stocks for the Lono Run: A Guide to Selecting Markets for LongIerm Growth. Burr Ridge, IL: Irwin Professional Publishing.

U.S. Department of Labor, Pension and Welfare Benefits Administration, 1996, Private Pension Plan Bulletin: Abstract of 1992 Form 5500 Annual Reports. Washington: U.S. 
Government Printing Office.

U.S. General Accounting Office, 1995, Eederal Pensions: Thrift Savings Plan Has Key Role in Retirement Benefits, GAO/HEHS-96-1. Washington: U. S. General Accounting Office. U.S. General Accounting Office, 1996, 401(k) Pension Plans: Manx Take Advantage of Opportunity to Ensure Adequate Retirement Income, GAO/HEHS-96-176. Washington: U. S. General Accounting Office. 
40

Table 1: IRA and 401 (k) Participation, By Age and Income, 1891

\begin{tabular}{|c|c|c|c|c|c|}
\hline \multicolumn{6}{|c|}{ Age Category } \\
\hline Income & $25-35$ & $36-46$ & 45-66 & 65-65 & All \\
\hline \multicolumn{6}{|c|}{ IRA Participation } \\
\hline$<10$ & 3.8 & 10.1 & 6.0 & 14.8 & 7.8 \\
\hline $10-20$ & 4.8 & 0.8 & 12.8 & 24.1 & 9.7 \\
\hline $20-30$ & 8.3 & 15.4 & 24.8 & 37.0 & 18.6 \\
\hline $30-40$ & 14.8 & 20.0 & 31.3 & 46.7 & 24.7 \\
\hline $40-60$ & 17.8 & 33.0 & 47.3 & 60.6 & 36.6 \\
\hline $60-76$ & 23.0 & 38.7 & 50.2 & 63.4 & 41.1 \\
\hline$>76$ & 43.2 & 59.8 & 60.3 & 76.5 & 61.0 \\
\hline All & 13.2 & 20.3 & 35.3 & 43.8 & 27.1 \\
\hline \multicolumn{6}{|c|}{401 (k) Partioipation } \\
\hline$<10$ & 4.1 & 6.6 & 1.6 & 6.7 & 4.6 \\
\hline $10-20$ & 9.4 & 13.6 & 8.6 & 9.8 & 10.5 \\
\hline $20-30$ & 21.2 & 20.7 & 16.9 & 10.2 & 18.4 \\
\hline $30-40$ & 29.7 & 27.3 & 18.2 & 26.5 & 26.2 \\
\hline $40-60$ & 28.7 & 31.0 & 39.8 & 25.6 & 31.8 \\
\hline $50-76$ & 38.1 & 36.3 & 42.3 & 43.6 & 39.4 \\
\hline$>75$ & 4.2 & 30.5 & 46.3 & 31.7 & 41.3 \\
\hline All & 23.0 & 28.5 & 26.8 & 20.9 & 24.6 \\
\hline \multicolumn{6}{|c|}{401 (k) Perticipation Given Eligibility } \\
\hline$<10$ & 70.8 & 58.4 & 72.6 & 85.2 & 70.8 \\
\hline $10-20$ & 63.2 & 07.7 & $\mathbf{5 1 . 5}$ & 68.3 & 63.0 \\
\hline $20-30$ & 70.3 & 50.8 & 67.6 & 49.0 & 01.7 \\
\hline $30-40$ & 74.1 & 63.7 & 58.6 & 72.6 & 67.3 \\
\hline $40-50$ & 73.8 & 68.7 & 81.6 & 07.8 & 72.9 \\
\hline $60-76$ & 76.1 & 67.2 & 75.1 & 84.0 & 73.3 \\
\hline$>75$ & $\mathbf{8 0 . 2}$ & 83.8 & 88.1 & 86.7 & 85.8 \\
\hline All & 73.6 & 67.7 & 72.3 & 72.3 & 70.8 \\
\hline
\end{tabular}

Source: Poterbe, Venti, and Wise (1995a). Tabulatione are beeed on 1981 SIPP. 
Table 2: Prevalence of Retirement Saving Arrangements in HRS Population

\begin{tabular}{|c|c|c|c|c|c|c|}
\hline & $\begin{array}{l}\text { IRA } \\
\text { Ondy }\end{array}$ & $\begin{array}{l}401(k) \\
\text { Only }\end{array}$ & DC Only & $\begin{array}{l}\text { IRA and } \\
401(k)\end{array}$ & $\begin{array}{l}\text { Other } \\
\text { Multiple }\end{array}$ & None \\
\hline$<10 K$ & $23.6 \%$ & $2.0 \%$ & $3.9 \%$ & $2.7 \%$ & $3.2 \%$ & $64.7 \%$ \\
\hline $10-20 K$ & 19.3 & 5.3 & 6.4 & 2.4 & 2.6 & 63.1 \\
\hline $20-30 K$ & 24.2 & 5.3 & 7.2 & 5.9 & 6.0 & 51.4 \\
\hline $30-40 K$ & 28.4 & 6.6 & 7.2 & 7.4 & 6.6 & 43.9 \\
\hline $40-50 K$ & 31.3 & 8.0 & 7.2 & 7.3 & 9.1 & 37.0 \\
\hline $50-75 K$ & 33.6 & 6.6 & 6.1 & 11.4 & 12.8 & 29.6 \\
\hline$>75 K$ & 42.7 & 4.1 & 4.4 & 15.8 & 19.0 & 14.0 \\
\hline ALL CATEGORIES & 28.7 & 5.3 & 6.0 & 7.4 & 8.4 & 44.4 \\
\hline
\end{tabular}

Notes: Authors calculations using Health and Retirement Survey data base. Income is defined as the sum of wage income, professional practice income, and income from a second job; it is essentially a labor income concept. The unit of measurement is the household. 
Table 3: Share of IRA, SRA, or Defined Contribution Pension Assets in Equities, 1992

Aae Group

$\begin{array}{llll}<35 & 50.5 \% & 44.7 \% & 47.9 \% \\ 35-44 & 50.4 & 44.5 & 46.4 \\ 45-54 & 51.7 & 49.3 & 50.8 \\ 55-64 & 51.7 & 45.4 & 49.1 \\ >65 & 33.0 & 39.8 & 49.6\end{array}$

Income Group

$<30$

30-50

$50-100$

$>100$

Total
$32.4 \%$

41.4

47.2

52.2

46.5
$37.5 \%$

41.8

38.1

56.0

46.8
$45.4 \%$

47.7

49.2

50.0

Source: Authors' tabulations from 1992 Surver of Consumer Finances. SCF respondents with IRAs are asked whother their assets are held in various asset categories, such as "Bank Accounts, CDs, and Money Market Funds," "Stocks," "Bonds," "A Combination of Stocks and Bonds," etc. The fraction holding stocks is computed by adding together all holdings of those who report that they hold stocks, and $1 / \mathrm{N}$ times the holdings of those who reporting investing in combinations of $\mathrm{N}$ assets, one of which is stocks. For example, half of the assets of individuals reporting "A Combination of Stocks and Bonds" is added to the equity total. For $401(\mathrm{k}), 403(\mathrm{~b})$, and other defined contribution pension fund investments, the options are "mostly in stocks," "mostly in bonds," and "split between." We add those assets that are held mostly in stocks to half of the assets that are "split between" to compute the total equity investment in these eccounts. The $401(\mathrm{k})$ and $403(\mathrm{~b})$ category also includes assets in Supplemental Retirement Accounts; the Traditional DC Pension Plan entries include ESOPs and profit sharing plans. 
Table 4: Distribution of IRA Assets, 1989 and 1994

\begin{tabular}{lll}
\hline Intermediary or Asset & 1989 & 1994 \\
\hline Commercial Bank & $21.8 \%$ & $14.5 \%$ \\
Thrifts & 21.5 & 8.0 \\
Life Insurance Companies & 8.3 & 8.2 \\
Credit Unions & 5.8 & 3.5 \\
Mutual Funds & 24.6 & 31.1 \\
- Equity Funds & 11.5 & 16.7 \\
- Money Market Funds & 5.6 & 8.7 \\
- Bond \& Income Funds & 7.5 & 5.6 \\
Other Self-Directed & 18.1 & 34.6 \\
\hline
\end{tabular}

Source: Investment Company Institute (1995). 
Table 5: Asset Allocation in $401(k)$ Plans

Panel A: Access Research (1995)

Asset Category

Corporate Equities

Company Stock

GICs

Balanced Funds

Bands

Money Market Funds

Other
1991

$11 \%$

26

31

13

5

9

6

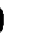

1993

1995

$16 \%$

$21 \%$

24

22

23

14

8

7

6

Panel B: RogersCasey and Institute of Management and Administration (1995)

$\begin{array}{llll} & 1988 & 1992 & 1995 \\ \text { Corporate Equities } & 43 & 47 & 55 \\ \text { GICs } & 44 & 38 & 28 \\ \text { Balanced, Bonds \& Cash } & 13 & 15 & 17\end{array}$

Source: Various reports as indicated in references. 
Table 6: Investment in $\mathbf{4 0 1}(\mathrm{k})$ Asset Categories, by Investment Availability

\begin{tabular}{|c|c|c|}
\hline Investment Option & Availability & $\begin{array}{l}\text { Use Given } \\
\text { Available }\end{array}$ \\
\hline \multicolumn{3}{|l|}{ Equity Funds: } \\
\hline $\begin{array}{l}\text { Long Term Growth } \\
\text { Growth and Income } \\
\text { Aggressive Growth } \\
\text { International } \\
\text { Index Fund } \\
\text { Company Stock }\end{array}$ & $\begin{array}{l}59.6 \% \\
52.1 \\
45.1 \\
27.1 \\
33.7 \\
41.6\end{array}$ & $\begin{array}{l}60.5 \% \\
64.0 \\
59.9 \\
50.1 \\
41.2 \\
59.4\end{array}$ \\
\hline Balanced Funds & 23.9 & 58.7 \\
\hline \multicolumn{3}{|l|}{ Bond Funds: } \\
\hline $\begin{array}{l}\text { High Yiald Bond } \\
\text { Long Term Bond } \\
\text { Corporate Bond } \\
\text { US Government Bond } \\
\text { Short Term Bond }\end{array}$ & $\begin{array}{c}13.6 \\
19.0 \\
9.2 \\
23.7 \\
9.8\end{array}$ & $\begin{array}{l}25.8 \\
32.7 \\
34.1 \\
29.6 \\
22.1\end{array}$ \\
\hline Guaranteed Investment Contract & 42.0 & 55.4 \\
\hline Money Market Fund & 35.9 & 36.4 \\
\hline $\begin{array}{l}\text { Asset Allocation Funds: } \\
\text { High Risk } \\
\text { Moderate Risk } \\
\text { Low Risk }\end{array}$ & $\begin{array}{l}15.4 \\
18.7 \\
14.1\end{array}$ & $\begin{array}{l}44.9 \\
43.4 \\
38.6\end{array}$ \\
\hline
\end{tabular}

Source: Access Rosearch (1995). 


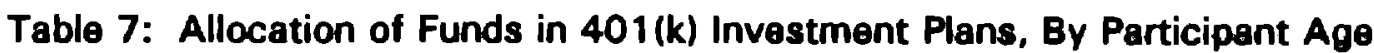

\begin{tabular}{|c|c|c|c|c|c|c|}
\hline \multirow[b]{2}{*}{$\begin{array}{l}\text { Investment } \\
\text { Category }\end{array}$} & \multirow[b]{2}{*}{ 21-30 } & \multirow[b]{2}{*}{$31-40$} & \multicolumn{2}{|c|}{ Age Group } & \multirow[b]{2}{*}{$>60$} & \multirow[b]{2}{*}{ Total } \\
\hline & & & $41-50$ & $51-60$ & & \\
\hline Stock Funds & $39.1 \%$ & $36.4 \%$ & $29.7 \%$ & $22.0 \%$ & $9.5 \%$ & $25.3 \%$ \\
\hline Company Stock & 11.0 & 8.9 & 6.1 & 5.8 & 2.7 & 6.1 \\
\hline $\begin{array}{l}\text { International } \\
\text { Stock Funds }\end{array}$ & 2.8 & 3.1 & 3.8 & 2.5 & 1.2 & 2.8 \\
\hline $\begin{array}{l}\text { Fixed-Income } \\
\text { Funds }\end{array}$ & 41.4 & 43.4 & 49.4 & 61.5 & 85.2 & 58.1 \\
\hline Belanced Funds & 5.7 & 8.2 & 11.0 & 8.3 & 1.3 & 7.8 \\
\hline
\end{tabular}

Source: Goodfellow and Schieber (1996). 
47

Table 8: Allocation of Funds in $\mathbf{4 0 1}$ (k) Investment Plans

\begin{tabular}{lrrrrrrrr}
\hline $\begin{array}{l}\text { Investment } \\
\text { Category }\end{array}$ & \multicolumn{10}{c}{ Income Group } & $15-25$ & $25-35$ & $35-45$ & $45-60$ & $60-75$ & $75-100$ & $100+$ \\
\hline Stock Funds & 24.6 & 21.5 & 19.5 & 18.6 & 25.3 & 42.2 & 45.4 & 52.0 \\
$\begin{array}{l}\text { Company Stock } \\
\text { International }\end{array}$ & 6.5 & 7.6 & 8.2 & 6.6 & 7.6 & 10.6 & 7.9 & 2.3 \\
$\begin{array}{l}\text { Stock Funds } \\
\text { Fixed-Income }\end{array}$ & 0.6 & 0.8 & 1.7 & 1.6 & 2.0 & 3.9 & 6.1 & 10.2 \\
Funds & 62.1 & 63.0 & 61.6 & 66.7 & 53.2 & 32.2 & 26.0 & 27.2 \\
Balanced Funds & 5.9 & 7.2 & 9.0 & 6.5 & 12.0 & 11.1 & 14.7 & 8.4 \\
\hline
\end{tabular}

Source: Goodfellow and Schieber (1996). 
Table 9: Participation In, and Salary Deferral Rates In, Federal Employee Retirement System

Salary

Range
10-19

20-29

30-39

$40-49$

$50-59$

$60-69$

$70+$

All
$45 \%$

69

81

89

93

93

96

73
$4.4 \%$

5.2

6.0

6.5

6.9

7.2

7.2

5.7

Source: General Accounting Office (1995). 
Table 10: Bonds vs. Equity: Current Investment Decisions and Asset Balances of TIAA-CREF Participants

\begin{tabular}{|c|c|c|}
\hline $\begin{array}{l}\text { Age or Income } \\
\text { in } 1993\end{array}$ & $\begin{array}{l}\text { Percentage of Contrib- } \\
\text { utions in TIAA Accounts }\end{array}$ & $\begin{array}{l}\text { Percentage of Assets } \\
\text { in TIAA Accounts }\end{array}$ \\
\hline
\end{tabular}

Total

$38 \%$

$44 \%$

Age:

$<35$

32

37

38

37

35-44

45-54

55-64

$65+$

44

45

53

49

57

Income:

$<25$

25- 34

50

53

35- 49

41

45

50- 74

39

46

75- 99

39

44

$>100$

35

42

34

40

Source: Unpublished tabulations from the 1993 Premium Paying Research Panel, TIAA/CREF Participants, courtesy of Brett Hammond. 
50

Table 11: Participant-Level Models for Share of TIAA-CREF Assets in TIAA

\begin{tabular}{|c|c|c|c|}
\hline Constant & $\begin{array}{l}67.33 \\
(6.68)\end{array}$ & $\begin{array}{l}49.19 \\
(4.99)\end{array}$ & $\begin{array}{l}62.81 \\
(6.92)\end{array}$ \\
\hline Age & $\begin{array}{l}-0.07 \\
(0.08)\end{array}$ & $\begin{array}{c}0.05 \\
(0.09)\end{array}$ & $\begin{array}{c}0.02 \\
(0.09)\end{array}$ \\
\hline Married & $\begin{array}{l}-0.05 \\
(2.02)\end{array}$ & $\begin{array}{c}0.88 \\
(2.02)\end{array}$ & $\begin{array}{c}0.28 \\
(2.03)\end{array}$ \\
\hline Female & $\begin{array}{c}4.07 \\
(1.84)\end{array}$ & $\begin{array}{c}4.76 \\
(1.79)\end{array}$ & $\begin{array}{c}3.70 \\
(1.86)\end{array}$ \\
\hline \multicolumn{4}{|c|}{ Family Income; } \\
\hline 25-50K & $\begin{array}{c}2.12 \\
(2.14)\end{array}$ & $\begin{array}{c}2.02 \\
(2.14)\end{array}$ & $\begin{array}{c}2.02 \\
(2.15)\end{array}$ \\
\hline $50-100 \mathrm{~K}$ & $\begin{array}{l}-1.86 \\
(2.12)\end{array}$ & $\begin{array}{l}-1.48 \\
(2.14)\end{array}$ & $\begin{array}{l}-1.11 \\
(2.15)\end{array}$ \\
\hline$>100 K$ & $\begin{array}{l}-6.76 \\
(2.70)\end{array}$ & $\begin{array}{l}-5.92 \\
(2.79)\end{array}$ & $\begin{array}{l}-5.21 \\
(2.79)\end{array}$ \\
\hline \multicolumn{4}{|l|}{ Education: } \\
\hline 12-16 Years & $\begin{array}{c}-10.15 \\
(5.04)\end{array}$ & & $\begin{array}{l}-9.54 \\
(5.04)\end{array}$ \\
\hline 16 Years & $\begin{array}{r}-11.97 \\
(4.78)\end{array}$ & & $\begin{array}{r}-10.76 \\
(4.79)\end{array}$ \\
\hline$>16$ Years & $\begin{array}{r}-13.88 \\
(4.26)\end{array}$ & & $\begin{array}{c}-12.31 \\
(4.29)\end{array}$ \\
\hline \multicolumn{4}{|l|}{ Net Worth: } \\
\hline 50-100K & & $\begin{array}{c}2.13 \\
(3.23)\end{array}$ & $\begin{array}{c}2.11 \\
(3.23)\end{array}$ \\
\hline $100-250 \mathrm{~K}$ & & $\begin{array}{c}0.52 \\
(2.22)\end{array}$ & $\begin{array}{c}0.42 \\
(2.22)\end{array}$ \\
\hline $250-500 \mathrm{~K}$ & & $\begin{array}{l}-4.94 \\
(2.33)\end{array}$ & $\begin{array}{l}-4.24 \\
(2.34)\end{array}$ \\
\hline$>500 \mathrm{~K}$ & & $\begin{array}{l}-5.66 \\
(2.54)\end{array}$ & $\begin{array}{l}-4.84 \\
(2.56)\end{array}$ \\
\hline Adj. $R^{2}$ & 0.0275 & 0.0260 & 0.0306 \\
\hline
\end{tabular}

Notes: All equations are estimated on a sample of 1190 observations in the 1988 TIAA-CREF Participant Survey. Standard errors are shown in parentheses. 
Table 12: TIAA-CREF Annuitant Responses to "How Would You Spend a $\$ 100,000$ Windfall?"

\begin{tabular}{|c|c|c|c|}
\hline & uy An Annuity & $\begin{array}{l}\text { Spend the Amount } \\
\text { Over 8-12 Years }\end{array}$ & $\begin{array}{l}\text { Annually Consume } \\
\text { No More Than Income }\end{array}$ \\
\hline Constant & $\begin{array}{c}0.295 \\
(0.265)\end{array}$ & $\begin{array}{c}0.411 \\
(0.254)\end{array}$ & $\begin{array}{c}0.294 \\
(0.292)\end{array}$ \\
\hline Age & $\begin{array}{c}0.002 \\
(0.004)\end{array}$ & $\begin{array}{l}-0.002 \\
(0.004)\end{array}$ & $\begin{array}{l}0.0002 \\
(0.004)\end{array}$ \\
\hline Married & $\begin{array}{l}-0.096 \\
(0.071)\end{array}$ & $\begin{array}{c}0.171 \\
(0.068)\end{array}$ & $\begin{array}{l}-0.075 \\
(0.079)\end{array}$ \\
\hline Female & $\begin{array}{l}-0.049 \\
(0.064)\end{array}$ & $\begin{array}{l}0.116 \\
(0.061)\end{array}$ & $\begin{array}{l}0.067 \\
(0.070)\end{array}$ \\
\hline $\begin{array}{l}\text { Social Security } \\
\text { Benefit Receipts (/1000) }\end{array}$ & $\begin{array}{l}0.025 \\
(0.067)\end{array}$ & $\begin{array}{l}-0.081 \\
(0.064)\end{array}$ & $\begin{array}{c}0.056 \\
(0.074)\end{array}$ \\
\hline Have Kids? & $\begin{array}{l}-0.095 \\
(0.071)\end{array}$ & $\begin{array}{l}-0.208 \\
(0.068)\end{array}$ & $\begin{array}{c}0.303 \\
(0.078)\end{array}$ \\
\hline \multicolumn{4}{|l|}{ Education: } \\
\hline 12-16 Years & $\begin{array}{l}0.083 \\
(0.112)\end{array}$ & $\begin{array}{l}-0.028 \\
(0.107)\end{array}$ & $\begin{array}{l}-0.054 \\
(0.123)\end{array}$ \\
\hline 16 Years & $\begin{array}{l}-0.022 \\
(0.115)\end{array}$ & $\begin{array}{l}-0.076 \\
(0.110)\end{array}$ & $\begin{array}{c}0.099 \\
(0.127)\end{array}$ \\
\hline$>16$ Years & $\begin{array}{l}-0.011 \\
(0.102)\end{array}$ & $\begin{array}{l}-0.015 \\
(0.098)\end{array}$ & $\begin{array}{l}0.026 \\
(0.113)\end{array}$ \\
\hline \multicolumn{4}{|l|}{ Nat Worth: } \\
\hline $50-100 K$ & $\begin{array}{l}0.041 \\
(0.102)\end{array}$ & $\begin{array}{c}0.189 \\
(0.097)\end{array}$ & $\begin{array}{l}-0.231 \\
(0.112)\end{array}$ \\
\hline $100-250 K$ & $\begin{array}{l}-0.059 \\
(0.073)\end{array}$ & $\begin{array}{c}0.164 \\
(0.070)\end{array}$ & $\begin{array}{l}-0.105 \\
(0.080)\end{array}$ \\
\hline 250-500K & $\begin{array}{l}-0.140 \\
(0.080)\end{array}$ & $\begin{array}{c}0.061 \\
(0.077)\end{array}$ & $\begin{array}{c}0.079 \\
(0.088)\end{array}$ \\
\hline$>500 K$ & $\begin{array}{l}-0.022 \\
(0.080)\end{array}$ & $\begin{array}{c}0.073 \\
(0.076)\end{array}$ & $\begin{array}{l}-0.052 \\
(0.088)\end{array}$ \\
\hline Adj. $R^{2}$ & 0.0049 & 0.0404 & 0.0590 \\
\hline
\end{tabular}

Notes: All equations are estimated on 310 observations with complete data on annuity demand in the 1988 TIAA-CREF Participant Survey. Standard errors are in parentheses. 
52

Table 13: Annuity Choices of TIAA-CREF Annuitants, 1978 and 1994

\begin{tabular}{|c|c|c|c|c|}
\hline Annuity Type & 1978 & 1994 & 1978 & 1994 \\
\hline Single Life: & \multicolumn{2}{|c|}{ Male Single-Life Annuitants } & \multicolumn{2}{|c|}{ Female Single-Life Annuitants } \\
\hline Without Guaranteo & $33.6 \%$ & $33.8 \%$ & $46.0 \%$ & $35.0 \%$ \\
\hline Ten-Year Certain & 38.2 & 25.8 & 30.5 & 29.8 \\
\hline Fifteen-Year Certain & 0.0 & 16.2 & 0.0 & 15.0 \\
\hline Twenty-Year Certain & 25.1 & 23.8 & 21.0 & 19.5 \\
\hline Installment Refund & 3.2 & 0.4 & 2.6 & 0.7 \\
\hline Joint Lifa: & \multicolumn{2}{|c|}{ Male Primary Annuitants } & \multicolumn{2}{|c|}{ Female Primary Annuitants } \\
\hline \multicolumn{5}{|c|}{ Full Annuity to Survivor: } \\
\hline Without Guaranteo & 5.6 & 13.3 & 2.2 & 11.7 \\
\hline Ten-Year Certain & 32.3 & 9.9 & 30.0 & 11.1 \\
\hline Fifteen-Year Certain & 0.7 & 13.0 & 0.0 & 14.6 \\
\hline Twenty-Year Certain & 63.1 & 63.8 & 67.8 & 62.6 \\
\hline \multicolumn{5}{|c|}{ Half Annuity to Survivor: } \\
\hline Without Guarantes & 7.2 & 14.2 & 2.4 & 12.6 \\
\hline Ten-Year Cortain & 37.0 & 8.9 & 45.9 & 12.3 \\
\hline Fifteon-Year Cortain & 1.0 & 12.2 & 0.0 & 22.2 \\
\hline Twenty-Year Certain & 54.7 & 64.7 & 51.8 & 52.9 \\
\hline
\end{tabular}

Source: Personal communication from Francis P. King at TIAA-CREF. 
Table 14: Wealth-Equivalent Value of Annuities Compared To "1/Life Expectancy" Consumption Plan

Annuity Market

Offers Real Annuities

Log Utility Case

$\begin{array}{ll}r=.03, \delta=.01 & .640 \\ r=.03, \delta=.03 & .666 \\ r=.05, \delta=.03 & .672 \\ \beta=2 \text { Case } & .501 \\ r=.03, \delta=.01 & .567 \\ r=.03, \delta=.03 & .618 \\ r=.05, \delta=.03 & \end{array}$

Log Utility Case

$\begin{array}{lll}r=.03, \delta=.01 & .672 & .688 \\ r=.03, \delta=.03 & .679 & .689 \\ r=.05, \delta=.03 & .700 & .702 \\ \beta=2 \text { Case } & & \\ r=.03, \delta=.01 & .538 & .684 \\ r=.03, \delta=.03 & .591 & .687 \\ r=.05, \delta=.03 & .659 & .703\end{array}$

Notes: Each entry shows the wealth required at age 65 to achieve the same expected lifetime utility as in the case without an annuity market, with a wealth at age 65 of 1 , and when the individual consumes (wealth/ife expectancy) each period. 